\title{
Delineation of groundwater potential zone in hard rock terrain in Gangajalghati block, Bankura district, India using remote sensing and GIS techniques
}

\author{
Sujit Das ${ }^{1}$ (1)
}

Received: 20 October 2017 / Accepted: 30 October 2017 / Published online: 8 November 2017

(C) The Author(s) 2017. This article is an open access publication

\begin{abstract}
This study employed with the integration of remote sensing (RS) and geographical information system (GIS) techniques to delineate ground water potential zones for ground water management of Gangajalghati block, Bankura district, West Bengal and is located on the eastern slope of Chotanagpur plateau and area belongs to predominantly Precambrian gneissic terrain, and small area belongs to Gondwana deposits and quaternary sediments. The groundwater in this region is confined within the weathered residuum and fracture zones in pediment region. Survey of India topographical maps and satellite imageries along with other data and field observation data have been utilized to prepare various thematic layers viz. drainage, slope, lineament, geology, hydrogeomorphic units, land-use/land cover, soil, and depth to water level map of this hard rock terrain. All the thematic map that influence ground water occurrences have been analyzed and integrated through GIS analysis based on weights assignment. The weighted index overlay method has been followed to delineate ground water potential zones. The result revealed that the study area can be categorized into four different ground water potential zones viz., very good, good, moderate, and poor zones. The bore well yield data reveals that medium yielding wells (50-100 L per min) are in and around the moderate to high lineament density zone and buried pediment medium region. Afterward validation with well yield data revealed a good correlation with respect to the observed ground water potential zonation. This study is useful for better planning and management of ground water resources as well as providing
\end{abstract}

Sujit Das

sujitdas.geo@gmail.com

1 Department of Geography, Visva Bharati-Vidya Bhavana, Santiniketan, Birbhum 731235, India quick prospective guides for ground water exploration in hard rock aquifer system.

Keywords Weathered residuum $\cdot$ Fracture zone $\cdot$ Hard rock terrain · Weighted index overlay method

\section{Introduction}

Ground water is a precious natural resource for the survival of human beings, as well as for the development aquatic and terrestrial ecosystems. Water bearing formation (interconnected fractures, lineament, etc.) of the earth's crust acts as conduits for transmission and as reservoirs for storing water. At present, all over the India as well as some other countries ground water resource depleting day by day which is not replenished sufficiently. So, an assessment for the ground water resource is extremely significant for the sustainable management of ground water systems in water deficit region. India is an agriculturally developed country and about $60-70 \%$ of the total population depends on it. Thus, the increasing agricultural and industrial development led to over exploitation is an important factor for the declination of ground water resources of the country.

Ground water in hard rock aquifers is essentially confined to fractured and weathered horizons. The occurrence and movement of ground water in a region of a hard rock terrain are mainly controlled by secondary porosity caused by fracturing of the underlying rocks. The study area i.e., Gangajalghati block, Bankura district, India, geologically belongs to Pre-Cambrian granite gneiss, lateritic mass and quaternary alluvium. Chotanagpur Gneissic Complex (CGC) consists of Archean gneiss, amphibolite, dolerite and pink granite/ biotite granite gneiss of different ages with enclaves of meta-sedimentaries which covers 
one-third area of the study area, so ground water occurrences are mainly concentrated to shallow overburden of weathered materials and fracture bed rocks. In the hard rock areas, the movement and occurrence of ground water depends mainly on the secondary porosity and permeability resulting from folding, faulting, fracturing, etc. while identification of potential ground water zones could aid in proper development and utilization of ground water resources for eliminating water scarcity (Rao 2006; Nag and Ghosh 2012). In the present study, mannerisms of monsoon and diverse physiographic conditions give rise to unequal spatial distribution of water, causing serious water scarcity in some region. Every year in summer time most surface water sources are dry up and majority of agricultural land depends on ground water extracted from dug wells and shallow tube wells. Unscientific excessive pumping of ground water has resulted in drying up most of the dug wells and tube wells, which in turn affects the livelihoods of the farmers (Das 2016).

Till now, several conventional methods such as geological, hydrogeological, geophysical and photogeological techniques were employed to delineate ground water potential zones (McNeill 1991; Teeuw 1995; Meijerink 1996; Sander et al. 1996; Edet and Okereke 1997; Taylor and Howard 2000; Shahid et al. 2000; Srivastava and Bhattacharya 2006). A number of workers such as Edet and Okereke (1997), Murthy (2000), Obi Reddy et al. (2000), Pratap et al. (2000), Singh and Prakash (2002) and Jaiswal et al. (2003), Chowdhury et al. (2009), Magesh et al. (2012) and Nag and Ghosh (2012) and others have used GIS techniques to delineate ground water potential zone. In recent years, extensive use of satellite data along with conventional maps and rectified ground truth data has made it easier to establish the base line information for ground water potential zones (Tiwari and Rai 1996; Das et al. 1997; Thomas et al. 1999; Harinarayana et al. 2000; Muralidhar et al. 2000; Chowdhury et al. 2010).

With the advent of powerful computer, digital technology integrate various conventional methods with remote sensing and geographical information system (GIS) technique helps to increase the accuracy of results in hydrogeological researches as well as delineation of ground water potential zones in any region. Furthermore, many authors such as Krishnamurthy et al. (1996), Murthy (2000), Sreedevi et al. (2001), Sikdar et al. (2004), Srivastava and Bhattacharya (2006), Fashae et al. (2014), Ghosh et al. (2015) and others have applied both remote sensing techniques and GIS applications in ground water exploration, delineation of ground water potential zones as well as identification of artificial recharge sites. Delineating the ground water potential zones using remote sensing and GIS is an effective tool for the proper evaluation, exploitation and management to ensure sustainable development of this seemingly valuable resource in this region.
Keeping this fact in mind, it is necessary to understand different types of geological structures, rock types, different hydrogeomorphic units and their characteristics and how hydrological characteristics are evolved in different geomorphic units, in order to demonstrate the integrated remote sensing and GIS-based methodology for understanding the geohydrological condition and identification of ground water potentiality in the Gangajalghati block. Integration of remote sensing data and the geographical information system (GIS) by using Weightage Index Overlay method for the delineation of ground water resources has given impetus in the field of ground water research, assessing, monitoring and management. Furthermore, such integrated remote sensing and GIS approach enables manipulation of large data base for large areal extent covering, even in inaccessible areas (Singh et al. 2013), thus providing a synoptic view of large areas (with associated hydrological information) for rapid and cost effective assessment of ground water occurrences (Fig. 1).

\section{Study area}

The study area, Gangajalghati block, lies between $23^{\circ} 18 / \mathrm{N}-23^{\circ} 31 / \mathrm{N}$ latitude and $86^{\circ} 59 / \mathrm{E}-87^{\circ} 13 / \mathrm{E}$ longitude, covering an area of $327 \mathrm{~km}^{2}$. It is situated on the northern part of the Bankura district, West Bengal, India and is covered by Survey of India topographical map no. $73 \mathrm{M} / 2$ and $73 \mathrm{M} / 3$. The major river system in the study area is Sali river, Gandheshwari nadi and Tartora nadi. The relief of the area varies between 72 and $158 \mathrm{~m}$ above mean sea level. The topography of the study area is an undulating plain. The study area enjoys a sub topical climate with relatively high temperatures during summer season and low temperature during winter season. The annual average rainfall in the district is around $1350 \mathrm{~mm}$, however about $80 \%$ of the rainfall occurs within the wet months from June to September. The maximum temperature rises to about $40-45^{\circ} \mathrm{C}$ by dry land winds and a minimum temperature of $12{ }^{\circ} \mathrm{C}$ (Das and Gupta 2014; HDR 2007; Sarkar and Das 2012). The principal soil series are loamy skeletal mixed Typic Ustorthents (38.1\%), fine loamy mixed hyperthermic Ultic Paleustlafs (26.4\%) and fine loamy mixed hyperthermic Typic Haplaquepts (14\%).

\section{Materials and methods}

Survey of India (SOI) topographical map $(73 \mathrm{M} / 2$ and $73 \mathrm{M} / 3,1: 50,000)$ has been used to prepare base, contour, drainage and slope maps. Satellite images from Indian Remote Sensing LISS-III (24.01.2011), on a scale of 1:50,000 (geo-coded, with UTM projection, spheroid and datum WGS 84, Zone 45 North) have been used 


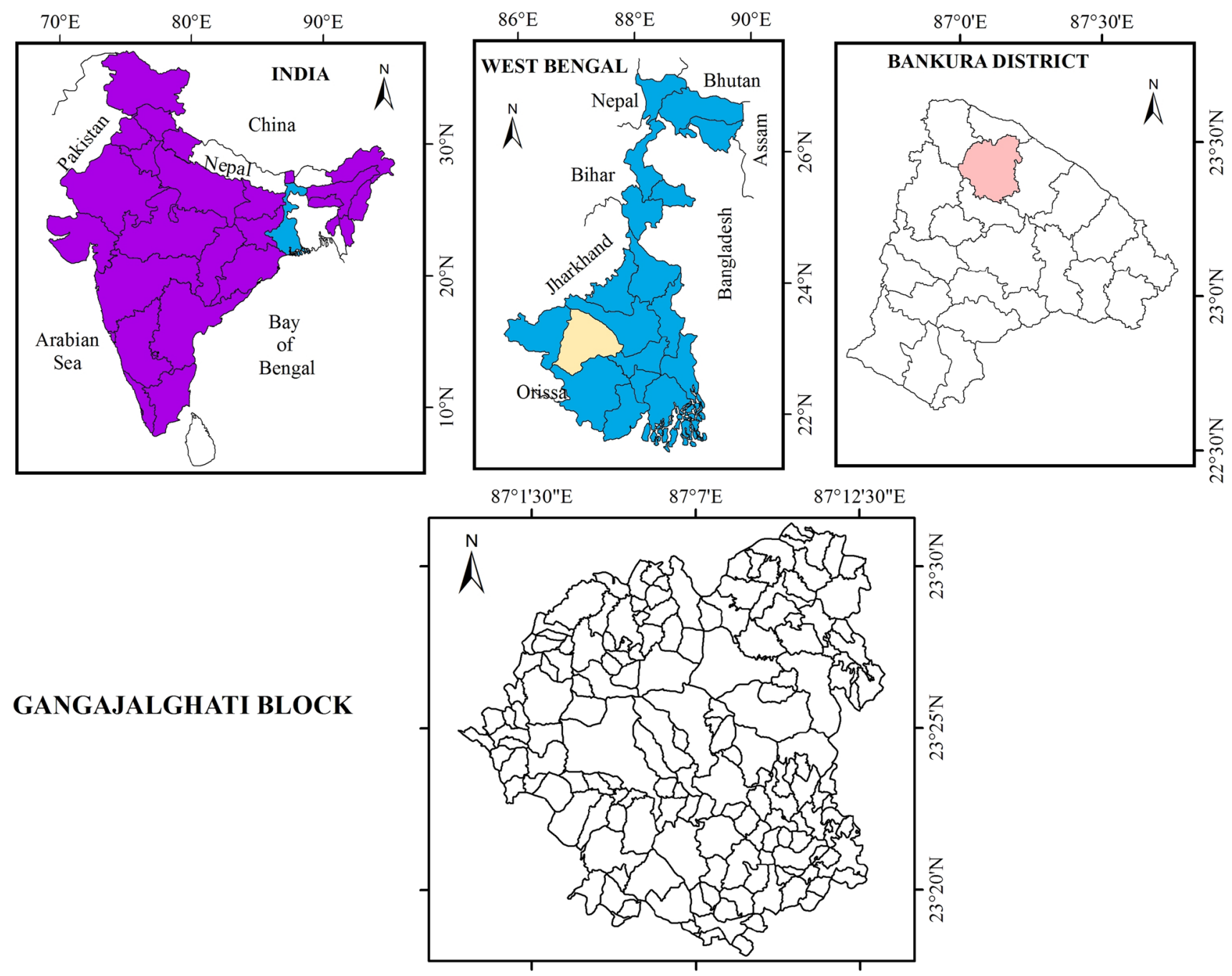

Fig. 1 Location map of the study area

for delineation of thematic layers such as lineaments, hydrogeomorphic units, and land-use/land cover by geostatistical analyst of Arc GIS. The geological map is generated with the help of District Resource Map of Bankura district (2001) and quadrangle map 73M (GSI 1985). The soil texture map has been prepared from National Bureau of Soil Survey and Land use Planning (NBSS and LUP 1992) data. Depth to water level and bore well yield data have been collected from different wells during field study (2013-2014). The ground water potential zones have been obtained by overlaying all the thematic maps in terms of weighted overlay methods using the spatial analysis tool in ArcGIS 10. During weighted overlay analysis, the ranking has been given for each individual parameter of each thematic map, and weights were assigned according to the multi influencing factor (MIF) of that particular feature on the hydro-geological environment of the study area (Shaban et al. 2006; Magesh et al. 2012).

\section{Result and discussion}

\section{Geological and hydrogeological settings}

Geology/lithology plays an important role in the distribution and occurrence of soil as well as ground water in any region. The underlying geology of north and north-western part are comprises mainly Pre-Cambrian granite gneiss, amphibolite, dolerite and pink granite/ biotite granite gneiss of different ages with enclaves of meta- sedimentaries. The basement terrain of south and central part are underlying by lateritic mass and quaternary alluvium. Laterites and ferruginous 
latosols of lalgarh formation are of Tertiary to middle Pleistocene age (Das 2016).

From hydrogeological point of view, the study area maximum covers thick burden of weathered materials and fractured bedrock and there has been a developed significant aquiferous unit by weathered materials and fractured bedrock which forms potential ground water zone (Fig. 2).

\section{Hydrogeomorphology}

Geomorphology which reflects various landform and topographical features of an area is one of the most important criteria for delineation of ground water prospect zone. Surface water is one of the important geomorphological agents in the development and shaping of landscapes and landforms in any area; thus hydrogeomorphological studies are of importance in the planning and execution of ground water exploration. The hydrogeomorphology in the hard terrain is highly influenced by underlying geological formation. The area is characterized by a dominant rocky terrain as well as undulating surfaces with lateritic upland and rolling plain land.

Remote-sensing studies provide an opportunity for better observation and more systematic analysis of various hydrogeomorphic units, lineaments, features following the

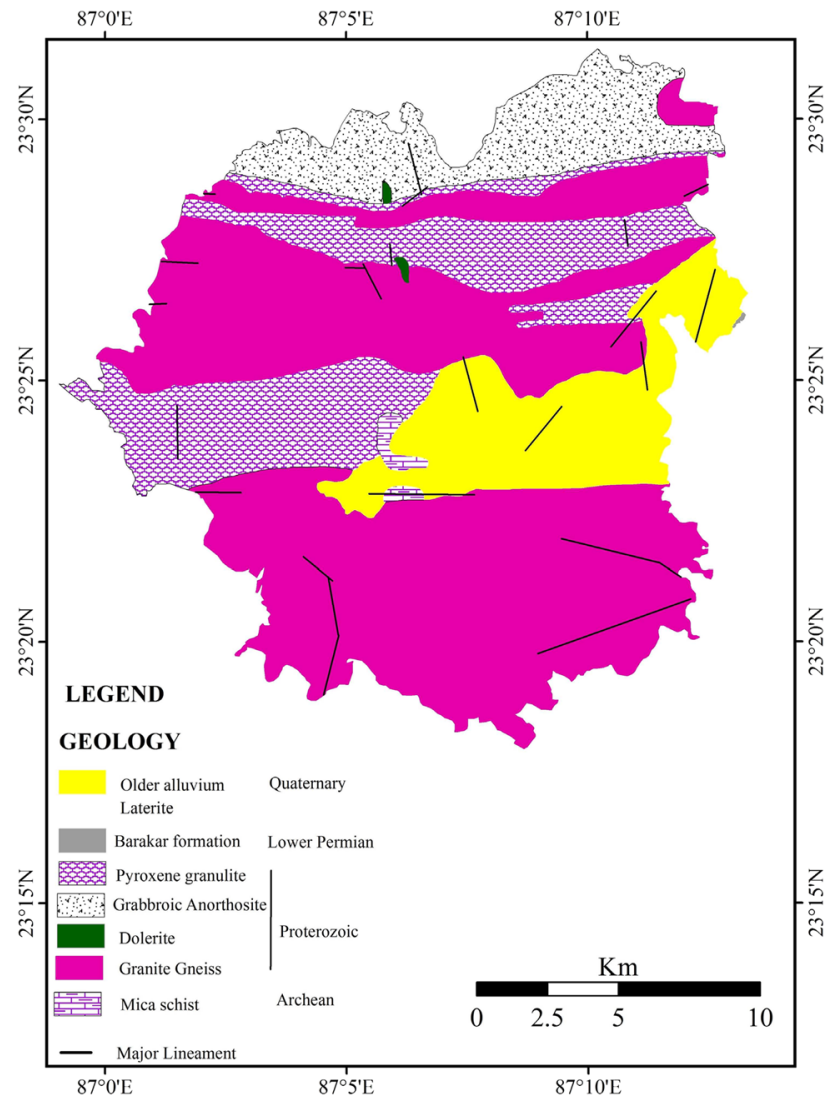

Fig. 2 Geological map (Based on GSI 1985; DRM 2001) of the study area

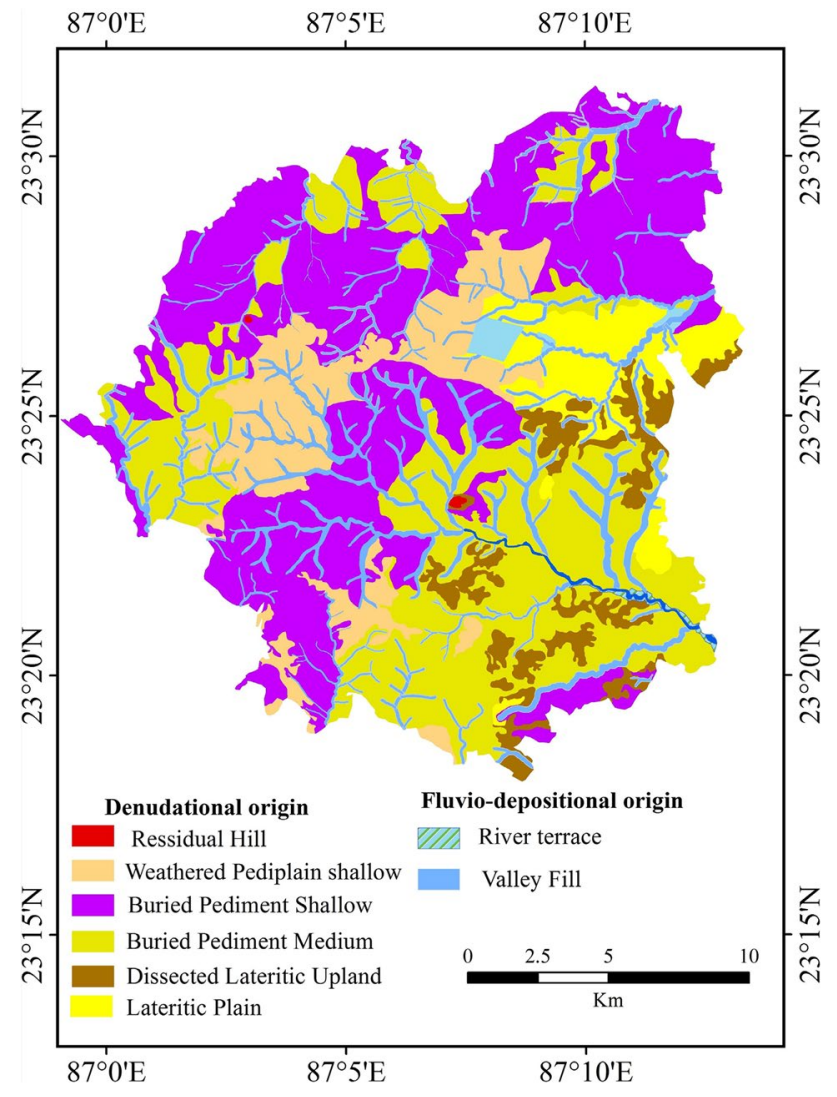

Fig. 3 Hydrogeomorphological map of the study area

synoptic, multispectral repetitive coverage of the terrain (Horton 1945; Kumar and Srivastava 1991; Sharma and Jugran 1992; Chatterjee and Bhattacharya 1995; Tiwari and Rai 1996). A number of hydrogeomorphic units have been identified in this region using IRS LISS III images (Fig. 3).

\section{Weathered pediplain shallow}

Weathered pediplain shallow are constituted of unconsolidated weathered mantle (regolith), with a negligible thickness ( $0-8 \mathrm{~m})$ and in situ scattered fractured weathered materials. This unconsolidated layer and fractured weathered material act as aquifers which have a high porosity and a low permeability (Acworth 1987).

\section{Buried pediment shallow (BPS)}

These are areas of nearly flat to gently sloping topography with shallow to moderately deep $(0-5 \mathrm{~m})$ red loamy coarsetextured soils followed by regolith zone. Ground water prospects are moderate to poor. 


\section{Buried pediment moderate (BPM)}

Buried pediment moderate mainly consists of unconsolidated weathered material overburden by thick alluvium or gravels greater than shallow pediplain and when saturated, this layer constitutes the reservoir of the aquifer.

\section{Dissected lateritic upland and lateritic plain}

The dissected lateritic upland areas are evident with the presence of dusky red to red skeletal soil followed by massive laterites and also dissected by rills, gullies and other erosional processes. Lateritic upland comprising mainly brown latosol with iron nodules (disintegrated duricrust) underlain by a lateritic hard pan (Das 2016).

\section{Valley fills}

Valley fill is the accumulation zone of colluvial materials derived from surrounding uplands, fine loamy to clayey soils with moderate to deep soil profile. Soils are basically hydromorphic in nature, it has very good porosity and permeability but sometimes the presence of clay may make it impermeable.

\section{Land-use and land cover}

Land use/land cover (LULC) plays important role in the occurrence and development of ground water in any region. The major LULC classes are agricultural land (60\%), dense deciduous forest (14\%), land with shrub (2\%), waste land (3\%), rural settlement (12\%) and water bodies (3\%). These LULC classes are delineated by visually interpretation of IRS LISS III satellite data and intense field verification (Fig. 4).

\section{Slope}

Slope is an important factor for the identification of ground water potential zones in any region. Steeper slopes causes less recharge because of rapid runoff during rainfall, allowing insufficient time to infiltrate the surface and recharge the saturated zone (Rokade et al. 2007; Magesh et al. 2012; Gumma and Pavelic 2012; Selvam et al. 2012). The areas having less slope $(<1)$ considered excellent for ground water storage, because less run off and high infiltration. The areas having high slope $(>2)$ cause relatively high runoff and low infiltration hence it is unfavorable for ground water storage (Fig. 5).

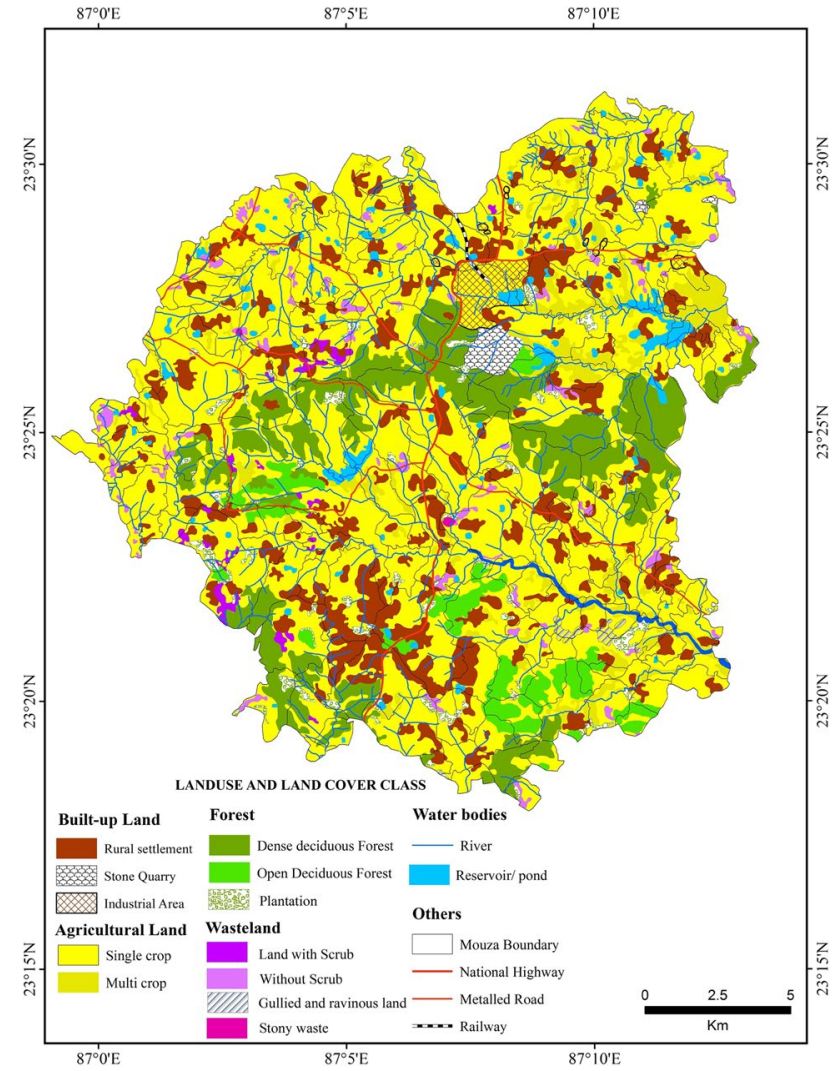

Fig. 4 Land-use and land cover map (Based on NRSA classification scheme 1990) of the study area

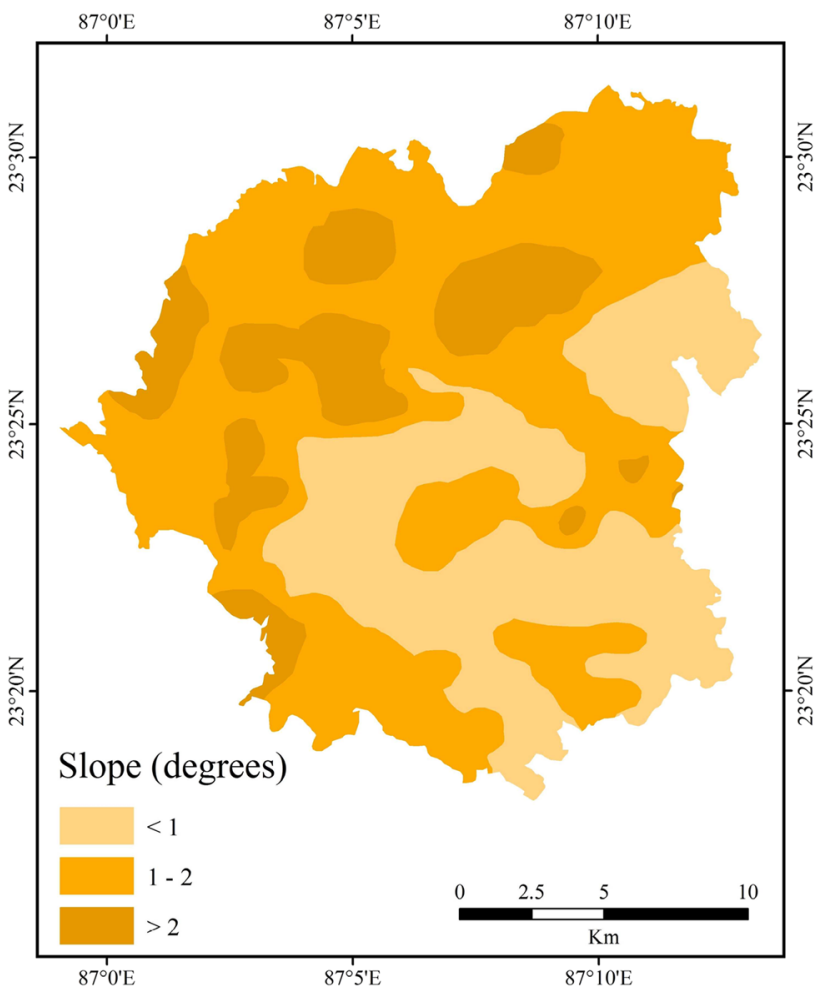

Fig. 5 Slope map (After Wentworth method) of the study area 


\section{Lineament and lineament density}

Lineaments are natural, linear fractures like faults, joints and fractures which can be interpreted directly from satellite imagery. By visually interpreting the satellite imagery, the lineaments of the study area are picked up and traced on the basis of tonal, textural, soil tonal, vegetation, topographic and drainage linearity, curvilinear ties and rectilinear ties (Drury 1990; Gupta 1991; Lillesand and Kiefer 1994). Lineaments represent the zones of faulting and fracturing in the bed rocks resulting in increased secondary porosity and permeability. These factors are hydro-geologically very important as they provide the path ways for ground water movement and enhanced well yields can be expected (Magesh et al. 2011; Subba Rao et al. 2001). The study area is crisscrossed with numerous lineaments in the north-western part due to rock type and tectonic activity in the past. The rocks are mainly composed of igneous and metamorphic rocks in Archean and middle Proterozoic age. Thus areas with higher lineament density are regarded as good for ground water potential. The high lineament density region assigned with higher weightage which are closely associated with area underlain by pyroxenite, pink granite, and mica schist.

To determine the lineament density in the study area, the study area is subdivided into a square grid $(1 \mathrm{~km} \times 1 \mathrm{~km})$. The lineament density of a single grid has been obtained from the values of the total length of the lineaments in a single grid ( $\mathrm{Sl}$ ) per unit area (A). The lineament density is obtained from the following formula:

$\mathrm{Ld}=\mathrm{Sl} / \mathrm{A}$

where Ld is the lineament density, 'Sl' is the length of lineament and ' $\mathrm{A}$ ' is the area. Considering the lineament density value of the each grid isopleth method have been employed to prepare lineament density map. The area with high lineament density is good site for ground water accumulation and has been important parameter for identification ground water prospect region in hard rock terrain (Fig. 6).

\section{Soil}

Soil texture plays an important role on the amount of infiltrating water in the ground and hence influences ground water recharge. The rate of infiltration largely depends on the soil texture and related hydraulic characteristics of the soils. The analysis of the soil type reveals that the study area is predominantly covered by red sandy loam soil (in shallow buried pediments and moderately buried pediments); silty clay loam and clay loam soil covered in valley fill (Fig. 7a; Table 1).

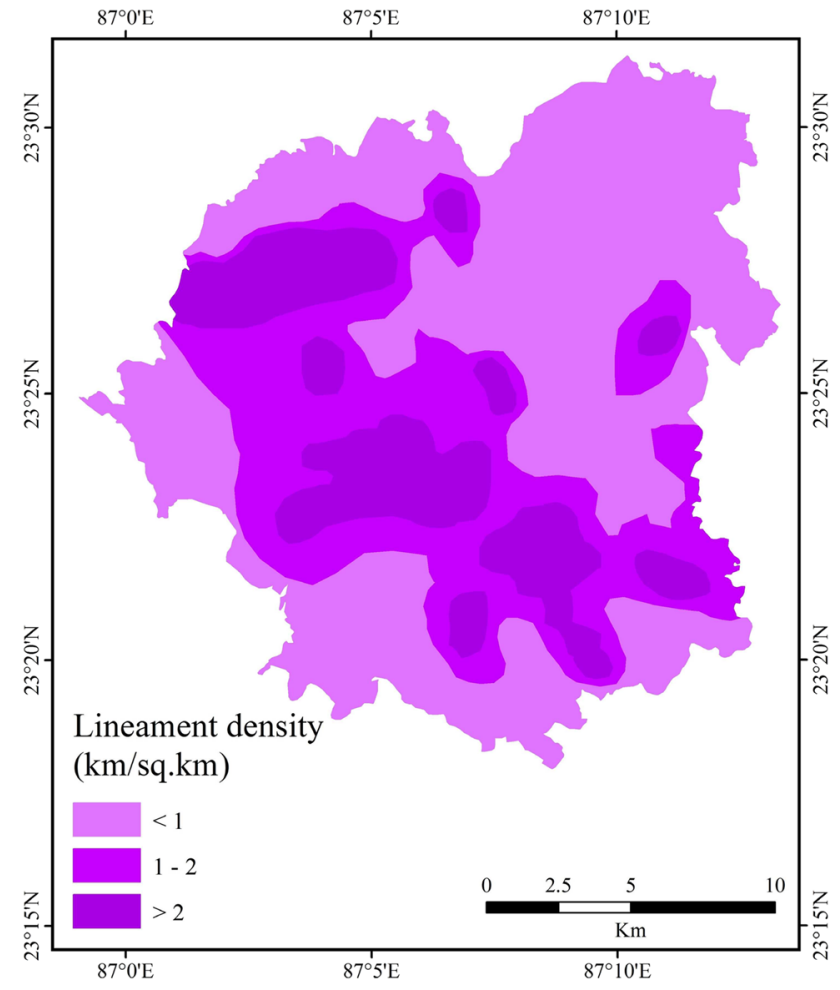

Fig. 6 Lineament density map (Based on satellite imageries and quadrangle map $73 \mathrm{M}$ ) of the study area

\section{Validation with borehole yield data}

In the northern part of the study area is characterized by pediment of varying weather residuum (BPS and BPM) but in some of that area water is retained throughout the year, due to unconsolidated weathered material of varying lithology, moderate slope and lineaments play an important role in recharging the ground water. During summer (pre-kharif) and winter season agricultural activity is not practiced in extensive area, so ground water discharge is relatively low. In lateritic part seasonal water level fluctuation is high and this area facing water scarcity during summer month. In lateritic formation surface runoff is high and lithomarge clay act as impervious strata to prevent percolated water moving further downward, so possibility of sub surface recharge is very poor (Table 2).

\section{Delineating the ground water potential zone}

The ground water potential zones for the study area have been generated through the integration of various thematic maps viz., drainage, slope, geology, hydrogeomorphology, land-use/land cover, lineament, and soil texture 

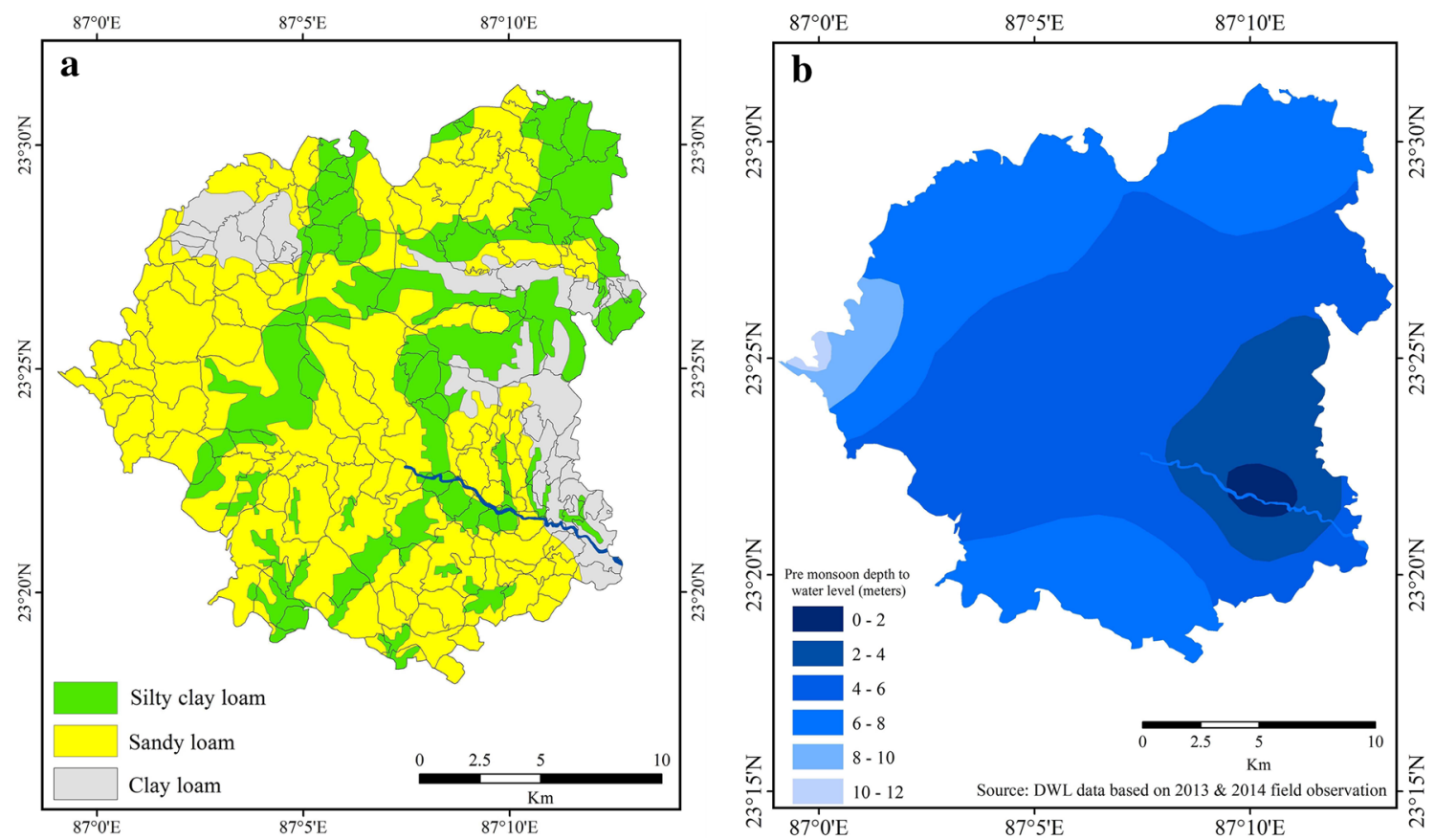

Fig. 7 a Soil texture map (Based on NBSS and LUP 1992; NRDMS 2014) and b depth to water level (pre monsoon) of the study area

Table 1 Weightage of different classes for identification of ground water prospect zone. Source: Extracted from different maps

\begin{tabular}{|c|c|c|}
\hline Theme & Class & Weightages \\
\hline \multirow[t]{5}{*}{ Hydro-geomorphological units } & Valley fill & 4 \\
\hline & BPM and lateritic plain & 3 \\
\hline & Buried pediment shallow & 2 \\
\hline & Dissected lateritic upland & 1 \\
\hline & Residual hill with pediments & 1 \\
\hline \multirow[t]{3}{*}{ Slope } & $<1^{\circ}$ & 5 \\
\hline & $1^{\circ}-2^{\circ}$ & 3 \\
\hline & $>2^{\circ}$ & 2 \\
\hline \multirow[t]{4}{*}{ Geology } & Alluvium & 5 \\
\hline & Granitic gneiss & 3 \\
\hline & Pyroxene granulite (anorthosite) & 2 \\
\hline & Laterite & 1 \\
\hline \multirow[t]{6}{*}{ Land use/land cover } & Water bodies & 5 \\
\hline & Double crop & 5 \\
\hline & Forest & 4 \\
\hline & Mono crop & 3 \\
\hline & Waste land (scrub land) & 2 \\
\hline & Built-upland & 1 \\
\hline \multirow[t]{3}{*}{ Lineament density } & $>2 \mathrm{~km} / \mathrm{km}^{2}$ & 5 \\
\hline & $1-2 \mathrm{~km} / \mathrm{km}^{2}$ & 3 \\
\hline & $<1 \mathrm{~km} / \mathrm{km}^{2}$ & 1 \\
\hline \multirow[t]{3}{*}{ Soil texture } & Sandy loam & 5 \\
\hline & Silty clay loam & 4 \\
\hline & Clay loam & 3 \\
\hline
\end{tabular}


Table 2 Characteristics of wells and their yield range in the study area. Source: NRSC/ISRO 2006, and ground truth and well observation during April-May, 2013-2014 and Nov, 2013-2014

\begin{tabular}{lll}
\hline Yield range of wells (LPM) & Aquifer material & Location and characteristics \\
\hline $20-30$ & Weathered rock & In north-western part in pediment region \\
$30-50$ & Weathered and fracture rock (impervious material) & $\begin{array}{c}\text { In the north-western part in buried pediment } \\
\text { shallow and lateritic upland } \\
\text { In the north-central part mainly characterized } \\
\text { by buried pediment medium }\end{array}$ \\
& Weathered material and fissured rock & $\begin{array}{l}\text { In the eastern part of lateritic plain } \\
\text { I00-200 }\end{array}$ \\
& $\begin{array}{l}\text { Loose sediments (clay) } \\
\text { Unconsolidated sediments mainly colluvium and alluvial channel fill (upper) and valley fill (lower) } \\
\text { fill }\end{array}$ & \\
\hline
\end{tabular}

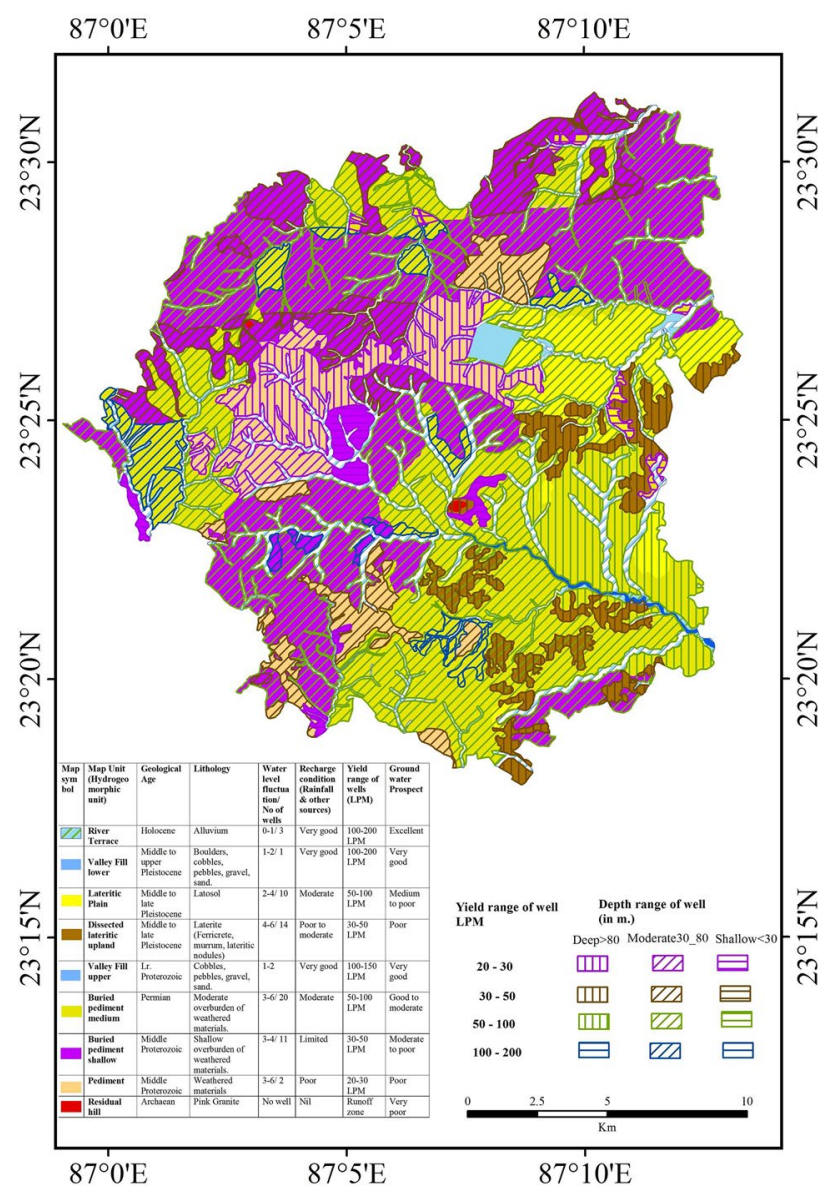

Fig. 8 Ground water prospect map of the study area

using remote sensing and GIS techniques. The weighted index overlay (WIO) method has been applied in this study where maps are analyses together in a weightage combination. Each thematic layer has been given weightage according to their strength. The ground water potential map (Fig. 8) demonstrates that the very good ground water potential zone is concentrated in the valley fills due to lineament intersection and lineament density is high to medium. In the hard rock terrain (western part) lineament act as direct conduits of ground water movement as a result depth to water level is shallow in the wells near the lineaments but in lateritic upland region (southern part) lineaments are in less, so ground water potentiality is very low and this area is not suitable for ground water targeting (Table 3).

\section{Conclusions}

Delineating the ground water potential zones in Gangajalghati block of Bankura district, West Bengal using remote sensing and GIS techniques enables quick decision-making for sustainable water resources management. To demarcate the ground water availability of the Gangajalghati block, various thematic maps such as, geology, hydrogeomorphology, lineament, slope, soil texture and depth to water level map have been prepared from geology map, remote sensing data, topographic maps, and conventional maps using Arc GIS software. The various thematic layers have been assigned proper weightage and then integrated in the GIS environment to prepare the ground water potential zone map of the study area. According to the ground water potential zone map, this area has been categorized into four different zones, namely very good (14\%), good (29\%), moderate $(42 \%)$, and poor $(15 \%)$. On overall analysis it is seen that the areas where lineaments are follow the drainage line and intersect with each other, covered with valley fills, are 
Table 3 Relationship between hydrogeomorphic units and ground water prospect in the study area. Source: Geocoded IRS P6 LISS III data dated 24th January 2011 and field survey during 2013-2014

\begin{tabular}{|c|c|c|c|}
\hline Hydrogeomorphic units & Structure/lithology & Characteristics & Ground water prospect \\
\hline Weathered pediplain shallow & $\begin{array}{l}\text { Fracture, lineaments etc.; varying lithol- } \\
\text { ogy }\end{array}$ & $\begin{array}{l}\text { Weathering process still continues and } \\
\text { different type of weathered rocks with } \\
\text { veneer of detritus material }\end{array}$ & Poor \\
\hline Buried pediment shallow (BPS) & Crisscross by lineaments and fracture & $\begin{array}{l}\text { Shallow overburden }(0-5 \mathrm{~m} \text { thickness }) \text { of } \\
\text { weathered materials; shallow to moder- } \\
\text { ately deep loamy skeletal soil }\end{array}$ & Moderate to poor \\
\hline Buried pediment medium (BPM) & Crisscross by lineaments & $\begin{array}{l}\text { Moderate overburden (5-2 0m thickness) } \\
\text { of weathered materials; moderately } \\
\text { deep to deep clayey or loamy skeletal } \\
\text { soil }\end{array}$ & Good to moderate \\
\hline Dissected lateritic upland & $\begin{array}{l}\text { Few lineament; mainly laterites as cap- } \\
\text { ping over granite and meta-sediments }\end{array}$ & $\begin{array}{l}\text { Lateritic nodules are evident in the } \\
\text { surface and hard duricrust formation } \\
\text { also noted in the subsurface indicate } \\
\text { polycyclic landscape; extensively dis- } \\
\text { sected by rill and gullies }\end{array}$ & Poor \\
\hline Lateritic plain & Occasionally lineaments are found & $\begin{array}{l}\text { Represent the toe slope segment of lat- } \\
\text { eritic upland and slope wash deposits; } \\
\text { ferruginous clayey soil }\end{array}$ & Medium to poor \\
\hline Valley fill (upper and lower) & $\begin{array}{l}\text { Constitutes of boulders, cobbles, pebbles, } \\
\text { gravel, sand and silt }\end{array}$ & $\begin{array}{l}\text { Accumulation zone of colluvial material } \\
\text { with moderate to deep soil profile }\end{array}$ & Very good \\
\hline River terrace & $\begin{array}{l}\text { Consists of river borne sediments mostly } \\
\text { alluvium }\end{array}$ & $\begin{array}{l}\text { Terrace presents along the river bed; } \\
\text { appropriate for double cropping; occa- } \\
\text { sionally flooding }\end{array}$ & Excellent \\
\hline
\end{tabular}

potential areas for ground water prospecting. Lineament also plays an important role to enhance the potentiality of the said unit in hard rock region and hence, depth to water level in the wells near the lineaments rises considerably during monsoon period. The hydrogeomorphological units such as valley fill and buried pediment medium are prospective zones for ground water exploration and development in the study area. The results obtained can be used for sustainable management of ground water resources in the area to conduct ground water exploration faster and efficiently. This method can be widely applied to a vast area with similar climate and geology (hard rock terrain) for the exploration of suitable sites for ground water exploration and development.

\footnotetext{
Acknowledgements The author is very grateful to Dr. Krishnendu Gupta, assistant professor, Visva Bharati for invaluable guidance and making constructive criticism extended during this work. I acknowledge the support given by the officials of Department of Science and Technology, Govt. of India; State Water Investigation Directorate, Govt. of West Bengal; Natural Resource Data Management System, Govt. of India; different administrative department in Bankura district and finally the local people in the said region.
}

Open Access This article is distributed under the terms of the Creative Commons Attribution 4.0 International License (http://creativecommons.org/licenses/by/4.0/), which permits unrestricted use, distribution, and reproduction in any medium, provided you give appropriate credit to the original author(s) and the source, provide a link to the Creative Commons license, and indicate if changes were made.

\section{References}

Acworth RI (1987) The development of crystalline basement aquifers in a tropical environment. Q J Eng Geol 20:265-272

Chatterjee RS, Bhattachaya AK (1995) Delineation of drainage pattern of a coal basin related inference using satellite remote sensing techniques. Asia Pac Remote Sens J 1:107-114

Chowdhury A, Jha MK, Chowdhury VM, Mal BC (2009) Integrated remote sensing and GIS-based approach for assessing groundwater potential in West Medinipur district, West Bengal, India. Ind J Remote Sens 30:231-250

Chowdhury A, Jha MK, Chowdary VM (2010) Delineation of groundwater recharge zones and identification of artificial recharge sites in West Medinipur district, West Bengal, using RS, GIS and MCDM techniques. Environ Earth Sci 59:1209-1222

Das S (2016) Applied geomorphological investigation for sustainable basin management: a study in Sali river basin, Bankura District, West Bengal. Unpublished Ph.D thesis, Dept. of Geography, Visva-Bharati

Das S, Gupta K (2014) Morphometric analysis of the polygenetic drainage basin: a study in Sali River, Bankura district, West Bengal. Geo Anal 4(1):11-23

Das S, Behera SC, Kar A, Narendra P, Guha S (1997) Hydrogeomorphological mapping in groundwater exploration using remotely sensed data-a case study in Keonjhar District, Orissa. J Indian Soc Remote Sens 25:247-259

District Resource Map (2001) Bankura District. Geological Survey of India, E.R, Kolkata

Drury SA (1990) Image interpretation in geology, 2nd edn. Chapman and Hall, London, p 281

Edet AE, Okereke CS (1997) Assessment of hydrological conditions in basement aquifers of the Precambrian Oban massif, southeastern Nigeria. J Appl Geophys 36(4):195-204 
Fashae OA et al (2014) Delineation of groundwater potential zones in the crystalline basement terrain of SW-Nigeria: an integrated GIS and remote sensing approach. Appl Water Sci 4(1):19-38

Geological Survey of India (1985) Geological quadrangle map. 73M

Ghosh PK, Bandyopadhay S, Jana NC (2015) Mapping of groundwater potential zones in hard rock terrain using geoinformatics: a case of Kumari watershed in western part of West Bengal. Model Earth Syst Environ 2:1. https://doi.org/10.1007/s40808-015-0044-z

Gumma MK, Pavelic P (2012) Mapping of groundwater potential zones across Ghana using remote sensing, geographic information systems, and spatial modeling. Environ Monit Assess. https://doi. org/10.1007/s10661-012-2810-y

Gupta RP (1991) Remote sensing geology. Springer, Germany, p 356

Harinarayana P, Gopalakrishna GS, Balasubramanian A (2000) Remote sensing data for groundwater development and management in Keralapura watersheds of Cauvery basin, Karnataka, India. Indian Mineral 34:11-17

Horton RE (1945) Erosional development of streams and their drainage basins: hydrophysical approach to quantitative morphology. Geol Soc Am Bull 56:275-370

Human Development Report (2007) District human development report: Bankura, development and planning department. Govt. of West Bengal, $\mathrm{p} 44$

Jaiswal RK, Mukherjee S, Krishnamurthy J, Saxena R (2003) Role of remote sensing and GIS techniques for generation of groundwater prospect zones towards rural development an approach. Int J Remote Sens 24:993-1008

Krishnamurthy JN, Venkatesa K, Jayaraman V, Manivel M (1996) An approach to demarcate ground water potential zones through remote sensing and geographical information system. Int J Remote Sens 17:1867-1884

Kumar A, Srivastava SK (1991) Geomorphological units, their geohydrological characteristics and vertical electrical sounding response near Munger, Bihar. J Indian Soc Remote Sens 19(4):205-215

Lillesand TM, Kiefer RW (1994) Remote sensing and image interpretation, 3rd edn. Wiley, New York, p. 750

Magesh NS, Chandrasekar N, Soundranayagam JP (2011) Morphometric evaluation of Papanasam and Manimuthar watersheds, parts of Western Ghats, Tirunelveli district, Tamil Nadu India: a GIS approach. Environ Earth Sci 64:373-381

Magesh NS, Chandrasekar N, Soundranayagam JP (2012) Delineation of groundwater potential zones in Theni district, Tamil Nadu, using remote sensing, GIS and MIF techniques. Geosci Front 3(2):189-196. https://doi.org/10.1016/j.gsf.2011.10.007

McNeill JD (1991) Advances in electromagnetic methods for groundwater studies. Geoexploration 27:65-80

Meijerink AMJ (1996) Remote sensing applications to hydrology: groundwater. Hydrolo Sci J 41(4):549-561

Muralidhar M, Raju KRK, Raju KSVP, Prasad JR (2000) Remote sensing applications for the evaluation of water resources in rainfed area, Warangal district, Andhra Pradesh. Indian Mineral 34:33-40

Murthy KSR (2000) Groundwater potential in a semi-arid region of Andhra Pradesh: a geographical information system approach. Int J Remote Sens 21(9):1867-1884

Nag SK, Ghosh P (2012) Delineation of groundwater potential zone in Chhatna Block, Bankura District, West Bengal, India using remote sensing and GIS. Environ Earth Sci. https://doi.org/10.1007/ s12665-012-1713-0

National Bureau of Soil Survey and Land use Planning (1992) The Soils of Bankura District (West Bengal) for Land use Planning. ICAR, Soils Bulletin NBSS Publication No.33, Nagpur, p. 4

NRDMS (2014) Natural Resource Data Management System-Department of Science and Technology (GOI) Project on Bankura soil texture map, Bankura district, West Bengal
NRSA (1990). Description and classification of land use/land cover. National Remote Sensing Agency, Department of Space, Hyderabad

NRSC/ISRO (2006). Groundwater prospect map (73M/2, M/3). Dept. of Space, Govt. of India. Sponsored by Rajib Gandhi National Drinking Water Mission, DDWS, Ministry of Rural Development, Govt. of India

Obi Reddy GP, Chandra Mouli K, Srivastav SK, Srinivas CV, Maji AK (2000) Evaluation of groundwater potential zones using remote sensing data - a case study of Gaimukh watershed, Bhandara district, Maharashtra. J Indian Soc Remote Sens 28(1):19-32

Pratap K, Ravindran KV, Prabakaran B (2000) Groundwater prospect zoning using remote sensing and geographical information system: a case study in Dala-Renukoot Area, Sonbhadra District Uttar Pradesh. J Indian Soc Remote Sens 28(4):249-263

Rao NS (2006) Groundwater potential index in a crystalline terrain using remote sensing data. Environ Geol 50:1067-1076

Rokade VM, Kundal P, Joshi AK (2007) Groundwater potential modeling through remote sensing and GIS: a case study of Rajura Taluka, Chandrapur District, Maharashtra. J Geol Soc India 69(5):943-948

Sander P, Chesley MM, Minor TB (1996) Groundwater assessment using remote sensing and GIS in a rural groundwater project in Ghana: lessons learned. Hydrogeol J 4(3):40-49

Sarkar A, Das S (2012) Integrated rural development: a study in Bankura District. Found Pract Geogr 16(10):126-135

Selvam G, Banukumar K, Srinivasan D, Selvakumar R, Alaguraja P (2012) Identification of ground water potential zone in hard rock terrain - a case study from parts of Manapparai block Tamilnadu using remote sensing and GIS techniques. Int J Adv Remote Sens GIS 1(1):8-18

Shaban A, Khawlie M, Abdallah C (2006) Use of remote sensing and GIS to determine recharge potential zone: the case of Occidental Lebanon. Hydrogeol J 14:433-443

Shahid S, Nath SK, Roy J (2000) Ground water potential modeling in soft rock area using GIS. J Remote Sens 21:1919-1924

Sharma D, Jugran DK (1992) Hydromorphological studies around Pinjaur-Kala Amb area, Ambala district (Hariana), and Sirmour district (Himachal Pradesh). J Indian Soc Remote Sens 29(4):281-286

Sikdar PK, Chakraborty S et al (2004) Land use/land cover changes and groundwater potential zoning in and around Raniganji coal mining area, Bardhaman District, West Bengal-a GIS and remote sensing approach. J Spat Hydrol 4(2):1-24

Singh AK, Prakash SR (2002) An integrated approach of remote sensing, geophysics and GIS to evaluation of groundwater potentiality of Ojhala sub watershed, Mirzapur District, U.P. India. https:// www.GISdevelopment.net

Singh AK, Panda SN, Kumar KS (2013) Artificial groundwater recharge zones mapping using remote sensing and GIS: a case study in Indian Punjab. Environ Earth Sci 62(4):871-881

Sreedevi PD, Srinivasulu S, Raju KK (2001) Hydrogeomorphological and groundwater prospects of the Pageru river basin by using remote sensing data. Environ Geol 40:1919-1924

Srivastava PK, Bhattacharya AK (2006) Groundwater assessment through an integrated approach using remote sensing, GIS and resistivity techniques: a case study from a hard rock terrain. Int J Remote Sens 27(20):4599-4620

Subba Rao N, Chakradhar GKJ, Srinivas V (2001) Identification of groundwater potential zones using remote sensing techniques in and around Guntur town, Andhra Pradesh, India. Photonirvaehak J Indian Soc Remote Sens 29(1, 2):69-78

Taylor R, Howard K (2000) A tectono-geomorphic model of the hydrogeology of deeply weathered crystalline rock: evidence from Uganda. Hydrogeol J 8(3):279-294 
Teeuw RM (1995) Groundwater exploration using remote sensing and a low-cost geographical information system. Hydrogeol J 3:21-30

Thomas A, Sharma PK, Sharma MK, Sood A (1999) Hydrogeomorphological mapping in assessing groundwater by using remote sensing data—a case study in Lehra Gage Block, Sangrur district, Punjab. J Indian Soc Remote Sens 27:31-42
Tiwari A, Rai B (1996) Hydromorphological mapping for groundwater prospecting using landsat-MSS images-a case study of Part of Dhanbad District, Bihar. J Indian Soc Remote Sens 24:281-285 